\title{
SENTENCIAS Y AUTOS DEL TRIBUNAL SUPREMO \\ $Y$ RESOLUCIONES DE LA DIRECCION GENERAL \\ DE LOS REGISTROS EN QUE SE CITAN, ESTUDIAN \\ O APLICAN PRECEPTOS CONSTITUCIONALES
}

POR

ENRIQUE LINDE PANIAGUA

Universidad Nacional de Educación a Distancia

\section{SUMARIO}

1. Repertorio de sentencias, autos y resoluciones por orden cronológico con transcripción de sus Considerandos básicos acompañados de un comentario y bibliografía sobre cada tema: A) Sentencias y autos del Tribunal Supremo.

\section{REPERTORIO}

A) Sentencias y autos del Tribunal Supremo

Núm. 1. Auto de 19 de enero de 1981. Civil. Ponente, J. de Castro García: ARTICULO 32.2 DE LA CONSTITUCION.

\section{Divorcio}

La ejecución en España de una sentencia extranjera de divorcio no es contraria al orden público interno por virtud de lo establecido en el artículo 32 de la Constitución.

\section{Antecedentes}

Auto de 24 de octubre de 1979 (núm. 11 del Repertorio de 1979).

Considerando: Que la cuestión de si en el momento actual el ordenamiento jurídico patrio permite oponer la excepción de orden público a la solicitud de exequátur de la sentencia sobre divorcio vincular de un español que ha contraído matrimonio civil en el extranjero con arreglo a la ley local ha sido resuelta ya por esta Sala en auto de 24 de octubre de 1979, que entendiendo superada la etapa preconstitucional definida por el principio de indisolubilidad de la unión conyugal, operando con aquel alcance a la hora de aplicar las normas de conflicto los tribunales del foro (sentencias de 12 de mayo de 1944, 30 de marzo de 1960, 23 de octubre de 1965, 5 de abril de 1966, 9 de marzo de 1968 y 12 de marzo y 29 de mayo de 1970, entre otras) e incluso prescindiendo de acudir al recurso del «efecto atenuado» $\mathrm{o}$ indirecto del orden público que utilizaran la sentencia de 22 de no- 
viembre de 1977 y las resoluciones de la Dirección General de los Registros de 18 de septiembre de 1971 y 23 de marzo de 1976, accedió a la homologación en España de una sentencia extranjera por la vía directa del exequátur no obstante la nacionalidad española de uno de los esposos, sosteniendo que el divorcio ba dejado de ser materia de orden público a efectos de lo prevenido en el artículo 12, párrafo $3 .^{\circ}$, del Código civil; criterio en el que se debe insistir atendiendo el cambio operado con la Constitución de 1978, determinante de que pueda ser conceptuada lícita en España tal decisión sobre divorcio vincular, porque no debe elevar a dicho rango más que las disposiciones y principios básicos - núcleo del orden social en expresión autorizada - al tiempo en que se postula la ejecución, ni es posible desconocer el contenido dinámico y cambiante del orden público, por lo que resulta incontestable que las afirmaciones de la suprema lex respecto de la libertad nupcial, y sobre todo anunciando la disciplina de las «causas de disolución», no permiten al presente atribuir a la indisolubilidad matrimonial el significado de un elemento de orden público en nuestro ordenamiento positivo, porque aun cuando el párrafo $2 .^{\circ}$ del artículo 32 no emplea el vocablo «divorcio», es obvio que el texto de la Ley Fundamental autoriza su implantación por el cauce de una ley ordinaria.

Considerando: Que por lo expuesto y de conformidad con lo dictaminado por el Ministerio Fiscal procede conceder el exequátur pretendido, dando cumplimiento a la sentencia pronunciada por el Juzgado de Primera Instancia - Tribunal Familiar- de Francfort-Main (Alemania) con fecha 8 de octubre de 1979, acordando el divorcio vincular en el matrimonio civil contraído el 14 de julio de 1972 en Bad Soden por doña C. F. y el súbdito español don E. H. G., disolución operada mediando conformidad de ambos cónyuges y habiendo expresado asimismo su anuencia la mujer a la efectividad en España de la resolución.

Ha Lugar al cumplimiento en España de la sentencia pronunciada por el Juzgado de Primera Instancia - Tribunal Familiar- de Francfort-Main (Alemania) con fecha 8 de octubre de 1979 sobre divorcio vincular del matrimonio civil contraído en Bad Soden (Alemania) por el súbdito español don E. H. G. y doña C. F.

\section{Comentario}

Véase comentario al auto de 24 de octubre de 1979 (núm. 11 de 1979).

Por otra parte, hay que considerar que en la actualidad ha sido promulgada la ley que modifica la regulación del matrimonio y establece las causas de separación, nulidad y divorcio. No obstante, está ley no estaba promulgada en la fecha en que se dictó la sentencia.

\section{Núm. 2. Sentencia de 28 de enero de 1981. Contencioso-Administrativo. Sala V. Ponente, J. Díaz de Lope-Díaz y López. ARTICULOS 9.3 Y 24 DE LA CONSTITUCION.}

Derecbo a obtener la tutela de jueces y tribunales.

Principio de jerarquía normativa.

La impugnación directa de normas de carácter general por entidades, corporaciones e instituciones no exige que el ámbito territorial de la representación corporativa de éstas coincida con el ámbito territorial de eficacia de la norma impugnada; esto por virtud de la eficacia de lo dispuesto en el artículo 24 de la Constitución.

Mera cita del principio de jerarquía. 


\section{Antecedentes}

Sobre el principio de jerarquía normativa, véase sentencia de 21 de octubre de 1980 (núm. 26 del Repertorio de 1980).

Considerando: Que como causas obstativas a la admisión del recurso, alega el abogado del Estado la falta de capacidad procesal del presidente de la Asociación Sindical, que aparece como tecurrente en nombre de dicha Entidad, y la falta de legitimación de la Asociación Sindical para impugnar y someter directamente a revisión la disposición de carácter general recurrida, constituida por el Decreto 264/1979, de 13 de febrero, aduciendo como fundamento de esta causa de inadmisibilidad la inadecuación entre la representación que ostenta la Asociación por ser de carácter provincial y los intereses presuntamente lesionados por el Decreto impugnado, que afectan a todos los funcionarios de la Administración Local.

Considerando: Que la primera causa de inadmisibilidad debe desestimarse atendiendo a que si la legitimación corporativa exige que quien interponga el recurso sea el órgano que pueda representar a la Entidad, según sus Estatutos, previa la formación de la voluntad corporativa a tenor de lo deterrminado estatutariamente, se han cumplido estos requisitos en el presente caso, pues según consta en el artículo 20 de los Estatutos de la Asociación, su Comisión Ejecutiva está facultada para tomar acuerdos relacionados con la interposición de toda clase de recursos y acciones ante cualquier órgano jurisdiccional, y en uso de esta facultad autorizó a su presidente para otorgar poderes a procuradores a los efectos de interponer el oportuno recurso contra el Decreto impugnado en este proceso, estando a su vez expresa y previamente autorizado el Consejo Ejecutivo por la Asamblea General de la Asociación para entablar la impugnación, todo ello con anterioridad a la interposición del recurso contencioso-administrativo, según consta en la certificación expedida por el secrtario de la Asociación unida a los autos en el trámites del artículo 129 de la Ley reguladora de la jurisdicción, concedida al recurrente para que subsanara el defecto procesal exigido en el artículo 57.2.b del propio ordenamiento al no haber acompañado a la demanda el documento acreditativo de la legitimación con que se presentaba en juicio.

Considerando: Que respecto a la segunda causa de inadmisibilidad no ignora esta Sala la reiterada doctrina jurisprudencial invocada por el abogado del Estado, que ha venido limitando la legitimación de las entidades, corporaciones e instituciones de Derecho público y cuantas entidades ostentaren la representación o defensa de intereses de carácter general o corporativo para impugnar directamente disposiciones de carácter general, interpretando que el ámbito territorial que abarca la competencia del ente que impugna debe ser el mismo a donde alcanza la norma objeto de impugnación, privando por ello de legitimación a los entes de competencia más reducida respecto de la impugnación de disposiciones generales de la Administración Central.

ConsIDERANDo: Que tal doctrina, basada en supuestos en que existía una organización jerárquica que contaba con un organismo superior de ámbito nacional al que estaban subordinados los de ámbito inferior, provincial o local, quiebra en virtud del derecho a la protección judicial instituido en el artículo 24 de la Constitución en cuanto concede a toda persona el derecho a obtener la tutela efectiva de los jueces y tribunales en el ejercicio de sus derechos e intereses legítimos, y aunque 
este derecho a la jurisdicción concebido en términos generales ha de conjugarse con los requisitos de la legitimación normalmente regulados en las leyes procesales, crea un ámbito amplio para ejercer la pretensión ante los órganos jurisdiccionales que permite admitir que la Asociación Provincial recurrente, constituida como persona jurídica al amparo del artículo 3..$^{\circ}$ de la Ley 19/1977, de 1 de abril, reguladora de la Asociación Sindical Profesional, cuyo artículo $10^{\circ}$ permite que puedan constituirse Asociaciones en cada rama de actividad a escala territorial o nacional con plena autonomía, sin relación de jerarquía entre ellas, está legitimada para impugnar directamente una disposición de carácter general de la Administración Central en cuanto en su marco territorial acoja, defienda y represente los intereses generales o corporativos a los que alude el artículo 28.1.b de la Ley reguladora de la jurisdicción, y concurriendo estas circunstancias de autonomía, interés legítimo y ausencia de normas limitadoras de la legitimación en este supuesto, procede la desestimación de la segunda causa de inadmisibilidad alegada por el abogado del Estado.

Considerando: Que la cuestión relativa al fondo del asunto está reducida a la procedencia o ilegalidad del número $2 .^{\circ}$ del artículo 8 del Decreto 264/1979, de 13 de febrero, sobre fijación de cuotas y pago de pensiones de la Mutualidad Nacional de Previsión de la Administración Local, en adelante abreviadamente Mutualidad, en cuanto dispone que dejará de cotizarse tanto por las corporaciones como por los funcionarios por las pagas extraordinarias, si bien subsistirá el incremento de la sexta parte de la base de cotización establecido por el artículo 13.4 de la Ley 11/1960, de 12 de mayo.

Considerando: Que la solución del problema exige partir de la ley creadora de la Mutualidad, la citada $11 / 1960$, de 12 de mayo, norma superior de rango legal hoy vigente a la que están referidas todas las disposiciones relacionadas con el tema de las prestaciones básicas complementarias y especiales concedidas en materia de derechos pasivos a los funcionarios de Administración Local, normativa que sólo puede ser modificada por otra de igual categoría en virtud del principio de jerarquia de normas tan arraigado en nuestro Derecbo, consagrado boy en el artículo 9.3 de la Constitución.

\section{Comentario}

La sentencia de 28 de enero de 1981 tiene enorme trascendencia desde el punto de vista de la interpretación del artículo 28.1.b de la Ley de la Jurisdicción Contencioso-Administrativa. En efecto, una jurisprudencia reiterada en los últimos años exigía que las entidades, corporaciones e instituciones, para poder impugnar disposiciones de carácter general, tuvieran como ámbito de extensión el del territorio nacional. Esta interpretación, que no se deducía del tenor literal del citado precepto de la Ley de la Jurisdicción Contencioso-Administrativa, se entiende con acierto quebrada por la aplicación directa del artículo 24 de la Constitución.

\section{Núm. 3. Sentencia de 7 de febrero de 1981. Criminal. Ponente, B. Gil Sáez. CONSTITUCION.}

Bandera española

Mera cita de la Constitución como texto que atribuye implícitamente a la bandera nacional la categoría de símbolo representativo de la nación. 


\section{Antecedentes}

Véase sentencia de 31 de octubre de 1980 (núm. 30 del Repertorio de 1980).

Considerando: Que dentro de la rúbrica general de «Delitos de traición» del Capítulo I, Título I, del Libro II del Código penal, queda tipificada en el artículo 223 un supuesto de traición ideal que difiere de las conductas materiales casuísticamente descritas en los tres artículos que le anteceden, en la que aparece ante todo el honor de la nación española como objeto de ataque, en los casos de ultrajes a la misma o al sentimiento de su unidad, así como a sus símbolos o emblemas, precepto incorporado al texto refundido del Código penal de 1944 proviniente de la Ley de Seguridad del Estado, cuyos precedentes se encuentran a su. vez en la Ley de 23 de marzo de 1906, llamada de Jurisdicciones, y en el artículo 231 del Código penal de 1928, siendo aquél modificado por Ley de 8 de abril de 1967, que extendió el ámbito delictivo a los ultrajes «al Estado o su forma política», que constituye el texto vigente actual, cuyos bienes jurídicamente protegidos se contraen a la nación española, al sentimiento de unidad, al Estado y su forma política y a los símbolos y emblemas, que son los signos externos que posean la cualidad de representar a determinadas realidades que no son particularmente señalados en el precepto repetido, pero que se desprenden de las disposiciones de nuestro ordenamiento jurídico positivo, que atribuyen a determinados signos la indicada indole representativa, cuya consideración merece la bandera nacional conforme al Código de Justicia Militar, la derogada Ley Orgánica del Estado y la actual Constitución, así como la jurisprudencia aplicada referente a este elemento objetivo (sentencias de 22-12-1909, 15-10-1947 y 21-11-1969); la acción que configura el delito es la de ultraje, equivalente a injuria, cuya noción es la misma que la definida en el artículo 457 del referido Código según tiene expresamente reconocido la doctrina de esta Sala, requiriéndose como elemento básico de la acción típica el animus iniurandi, o sea, el propósito de deshonrar y menospreciar a los objetos que entran en los bienes protegidos penalmente por cualquiera de los modos y formas que la acción de injurias admite, como la de arrancar y pisotear la bandera (sentencia de 6 de junio de 1908), y siendo así que los hechos probados de la sentencia impugnada arrojan sustancialmente que el recurrente, el 9 de julio de 1978, en la localidad de Pedreguer (Alicante), con motivo de las Fiestas Patronales, en la plaza principal y ante la mayoría de los vecinos, «con la llama que producida con los cohetes que sucesivamente encendía..., prendió fuego y quedaron destruidas al arder hasta catorce banderas españolas, que intercaladas con otras de la región valenciana estaban colocadas en los palcos y balcones», acción recriminada por el numeroso público que lo presenció, aparece inequívocamente reflejado el ultraje inferido a la insignia nacional por antonomasia, careciendo de consistencia fáctica y legal la alegación defensiva consistente en que, al no declararse en los hechos probados que al quemar dichas banderas obrara con intención de injuriar o ultrajar a dicho símbolo nacional, tal conducta no podía ser constitutiva de delito previsto y penado en el artículo 123 de referencia, alegación puramente subjetiva, parcial e interesada, por cuanto, de una parte, al eludir tal consignación expresa el tribunal de instancia, impidió que su resolución pudiera ser combatida por el defecto procesal de predeterminación del fallo por intercalación de conceptos jurídicos, pero que suficientemente aclaran, consignan y ratifican el ánimo injurioso de tal conducta al afirmar en el primer Considerando que tal acción de prender fuego y destruir por ignición dicho símbolo implicaba un móvil perverso de injuriar abiertamente los sentimientos del conjunto de personas que, como las que estaban presentes, integraban por historia, lenguaje, tradición y territorio común una sínte- 
sis colectiva de súbditos componentes del pueblo español, cuya acción además es por su propia índole tan notoria, manifiesta y trascendente que se califica por sí mismo sin necesidad de remarcarla especialmente, por cuanto no se trató de una o dos banderas que por puro accidente y azar al disparar los cohetes dispuesto para diversión del vecindario en fiestas pudieron verse alcanzadas por la llama que prendía la mecha de éstos, sino que tal acción se extendió a catorce de las mismas, separadas y disgregadas a través de los diversos lugares de la plaza principal de la población en que fueron colocadas, haciéndolo el procesado sucesivamente, con lo que no cabe en buena lógica y hasta por sentido común atribuir a tal acción otro significado por su propia exteriorización que el voluntario, libre y consciente propósito del inculpado de ultrajar las banderas bajo la mirada y repulsa de sentimientos de la numerosa concurrencia asistente $y$, de otra parte, que tan pública, ostensible y deliberada conducta no tuvo otro impulso, móvil y propósito que el injuriar o ultrajar y menospreciar a la nación española mediante la destrucción por el fuego del símbolo de tan alto significado como es su bandera representativa, como en supuestos menos graves que el ahora enjuiciado tiene declarado esta Sala, tal como el arrancar y pisar aquélla (sentencia de 6 de junio de 1968) o hacerla caer deliberadamente al suelo (sentencias de 25 de mayo de 1959 y 21 de noviembre de 1969), siendo un delito de simple actividad que se consuma cuando los actos ofensivos son percibidos por alguna persona (sentencia de 26 de junio de 1969'), concurriendo el ánimo de vituperar como dolo específico necesario en esta infracción, cuya finalidad e intención resalta clara, manifiesta y probada del factum probatorio y del contexto de la sentencia conforme al párrafo $2 .^{\circ}$ del artículo $1 .^{\circ}$ del Código penal, que al ser negado en el alegato defensivo correspondía probarlo al recurrente, lo que ni se ha hecho, ni siquiera se ha aportado razón o argumento alguno que dialécticamente sobrepase la mera invocación efectuada o indique al menos cuál era el móvil que impulsó a obrar a aquél en la forma que lo hizo, lo que consecuentemente conlleva a rechazar el único motivo del recurso amparado en el número $10^{\circ}$ del artículo 849 de la Ley de Enjuiciamiento Criminal, reputando infringido por aplicación indebida el artículo 123 de referencia, que apareciendo correcta y acertadamente estimado, procede confirmar y ratificar, sin que finalmente por este Alto Tribunal tenga que hacerse ninguna aclaración u objeción complementaria sobre el particular contenido en el fallo de la sentencia de proponer al Gobierno la conveniencia de rebajar la pena impuesta por otra de inferior duración.

\section{Comentario}

La sentencia de 7 de febrero de 1981 no hace sino citar la Constitución a los efectos de reforzar la tesis de la misma, según la que la bandera de España conforme al artículo 231 del Código penal es un bien jurídico protegido. Para el concepto de bandera española, véase sentencia de 31 de octubre de 1980 (núm. 30 de 1980).

Núm. 4. Sentencia de 17 de febrero de 1981. Contencioso-Administrativo. Sala IV. Ponente, J. M. Ruiz-Jarabo Ferrán. ARTICULO 24.2 DE LA CONSTITUCION

\section{Principio de presunción de inocencia}

La simple información de la autoridad policial no puede prevalecer sobre el principio de presunción de inocencia consagrado en el artículo 24.2 de la Constitución. 


\section{Antecedentes}

Sentencias de 27 de junio y 3 de julio de 1980 (núms. 8 y 9 del Repertorio de 1980).

Considerando: Que en el presente procedimiento contencioso-administrativo, y tal como acertadamente se destaca en la sentencia apelada, nos encontramos ante un supuesto en que ni del expediente administrativo ni de los autos resultan datos fehacientes que permitan configurar objetivamente la actuación de la sancionada, ya que sólo aparece del primero lo que podríamos denominar una simple opinión de la policía sobre la actuación de determinadas personas, no concretadas ni identificadas, que acudían al bar propiedad de aquélla con finalidades, a juicio de la autoridad informante, atentatorias a la moral o buenas costumbres, y como sólo el pleno conocimiento de los hechos, acreditados que sean éstos con una prueba concluyente, permitiría determinar si el comportamiento de la hoy apelada fue o no acreedor a la dura sanción impuesta y si, por tanto, la denuncia formulada contra aquélla era o no justa, resulta indudable que, ante la, repetimos, indicada falta de datos, sólo a la autoridad actuante imputable, y habida cuenta la presunción de que la actuación de toda persona ha de estimarse correcta en tanto no se acredite lo contrario, es pertinente la revocación del acuerdo del Gobierno Civil de Oviedo que dispuso la clausura del bat propiedad de la sancionada, lo cual es lógica consecuencia además del principió de que nunca el administrado puede hallarse en posición peor a la del delincuente, y por ello, si para condenar a éste es necesario la aportación de una prueba demostrativa de la realidad del ilícito penal del que es acusado, para sancionar a aquél es también necesario acreditar la constatación plena del fundamento fáctico de la sanción, y como nada de esto, insistimos, ocurrió en el presente caso, es por lo que, tal como ya adelantamos y asimismo declara con acierto la sentencia que se revisa, procede dejar sin efecto la sanción objeto de este recurso, ya que de lo contrario el principio proclamado en el artículo 24.2 de la vigente Constitución española de que toda persona tiene derecho a la presunción de inocencia sería conculcado al prevalecer frente a tal presunción la simple información de la autoridad actuante, aunque esta última no resulte en absoluto acreditada como debiera.

\section{Comentario}

Véanse sentencias de 27 de junio y 3 de julio de 1980 (núms. 8 y 9 del Repertorio de 1980) y sus respectivos comentarios.

Núm. 5. Sentencia de 20 de febrero de 1981. Contencioso-Administrativo. Sala V. Ponente, A. Agúndez Fernández. ARTICULOS 9.1, 97 Y 103 DE IA CONSTITUCION.

\section{Principio de legalidad}

Mera cita de los artículos 9.1, 97 y 103 de la Constitución.

\section{Antecedentes}

Sentencias de 11 de junio de 1979 (núm. 5 del Repertorio de 1979), 21, de octubre de 1980 (núm. 26 del Repertorio de 1980) y 12 de noviembre de 1980 (núm. 32 del Repertorio de 1980). 
Considerando: Que el abogado del Estado ha interpuesto el recurso de apelación extraordinario en interés del artículo 101 de la Ley de 27 de diciembre de 1956 contra la sentencia de la Sala de lo Contencioso-Administrativo de la Audiencia de Oviedo de fecha 17 de noviembre de 1978, que, habiendo estimado el de don E. F. C., declaró ilegal la convocatoria de concurso de traslado en el Cuerpo de Ingenieros Técnicos Industriales al servicio del Ministerio de Industria y Energía, realizada por la Resolución de la Subsecretaría de este Ministerio de 23 de diciembre de 1977, y acordó fueren incluidas en el concurso todas las vacantes existentes el día de su publicación en el Boletín Oficial del Estado el 11 de enero de 1978, especialmente la que existía en la Delegación Provincial de La Coruña servida por funcionario interino.

CoNSIDERANDO: Que conforme al citado precepto, este recurso de apelación en interés de la ley tiene el carácter de extraordinario, porque su régimen es distinto del ordinario de los artículos 94 a 96 de la dicha de 1956; además tiene el de excepcional en cuanto sólo se da contra sentencias no susceptibles de apelación normal y porque está atribuido a la Administración, defendida por el abogado del Estado, el privilegio de ser la única parte del proceso con legitimación para interponerlo, cuyos caracteres evidencian las restricciones a que está sujeto: las de no convertirse en apelación ordinaria, tener como motivo impugnatorio el de estimarse gravemente dañoso y errónea la resolución recurrida, formar jurisprudencia esta Sala al fijar la doctrina legal del caso, pero sin alteración de las situaciones jurídicas particulares, no excederse del tema debatido en la primera instancia y atenerse la apelación estrictamente a los términos de aquella sentencia y a los del suplico de las alegaciones del abogado del Estado.

Considerando: Que para prosperar el recurso, la sentencia impugnada, además de constituir grave daño en cuanto a los intereses de la Administración por la posterior repetición de los criterios en ella establecidos, ha de ser errónea en sus fundamentos y pronunciamientos. Cuando la ahora recurrida declaró la nulidad de la Resolución administrativa de convocatoria de concurso de traslado de ingenieros técnicos industriales y dispuso la convocatoria de nuevo concurso con inclusión de la plaza de La Coruña servida por funcionario interino, aplicando en su apoyo el artículo 27 del Reglamento del Cuerpo de fecha 19 de diciembre de 1975, se ajustó plenamente al ordenamiento jurídico sin incurrir en yerro alguno, porque si bien es cierto que la Administración, a tenor de los artículos 15 y 17 de la Ley de Régimen Jurídico de 26 de julio de 1957 posee, ejercitando sus potestades organizativas en materio de personal, facultades para convocar el número de vacantes de funcionatios conforme los exijan las necesidades del servicio público - principio general reconocido por la Sala, sentencias de 25 de octubre y 12 de noviembre de 1965, entre otras-, también es cierto que tales facultades tienen dos limitaciones: una, la del principio de legalidad que debe cumplir la Administración en todas sus actuaciones, imperativamente impuesto por los articulos 23 y 26 de la citada Ley de Régimen Jurídico, el 1.1 de la de Procedimiento Administrativo de 1958 y los 9.1, 97 y 103 de la Constitución de 1978, y otra, la de que hayan sido efectivamente ejercidas en beneficio del servicio público, con exclusión de cualquier clase de arbitrariedad infractora del ordenamiento jurídico según previenen los artículos 83.2 de la Ley de lo Contencioso-Administrativo de 1956 y 48.2 y 115.1 de la de Procedimiento Administrativo; limitaciones ambas operantes en el presente caso, así la primera porque rige la norma específica del Cuerpo, artículo 27 del Reglamento, Decreto 3.702 de 19 de diciembre de 1975 (a relacionar con el 56 de la Ley de Funcionarios de 1964), preceptiva de que la convocatoria del concurso in- 
cluirá las vacantes existentes en cada localidad, expresión equivalente a la de todas y cada una de las plazas vacantes en la localidad, como asimismo establecen los 23 y 34 la provisión de todas las plazas vacantes en los supuestos de reingreso y de nuevo ingreso, y por lo referente a la segunda, porque se produce efectivo beneficio para el servicio público cuando fue excluida del concurso de traslado la plaza cubierta por funcionario interino, conculcándose de esta manera los artículos 5.2 y 104.1 de la Ley de Funcionarios de 1964, que únicamente permiten el nombramiento de interino por razones de urgencia o necesidad y hasta tanto se provea la plaza por funcionario de carrera según el régimen normal, como en el supuesto actual sucedió.

ConsIDERANDo: Que, finalmente, nada desvirtúan los anteriores razonamientos, primero, la alegación del abogado del Estado basada en distinguir plantilla orgánica de plantilla presupuestaria, pues ambas han de coincidir en cuanto se trate de vacantes a cubrir en propiedad, conforme a la dotación del correspondiente capítulo del Presupuesto, siendo vacante presupuestaria la cubierta por funcionario interino, cual es el caso presente, y. segundo, la afirmación del jefe de la Sección de Personal de Cuerpos Especiales del Ministerio de Industria y Energía, certificación de antecedentes fecha 12 de julio de 1978, de que tal funcionario interino (nombrado por Orden de 31 de marzo de 1977) adquirió derecho a permanecer en el empleo durante plazo de cinco años, en virtud del Decreto-ley 22, de 30 de marzo de 1977, es rechazable porque la disposición adicional primera, dos, de este Decretoley únicamente le concedió derecho a continuar hasta el momento en que la plaza fuere provista por el correspondiente procedimiento efectivo, es decir, como aquí ocurre, el de traslado normal, para el que debió incluirse tal plaza y así lo dispuso la sentencia de la Audiencia.

Considerando: Que, por tanto, resulta improcedente acceder a la pretensión del abogado del Estado, contenida en el suplico de sus alegaciones, y en lo que al presente caso respecta, de fijarse la doctrina legal de que «la Administración no se encuentra obligada en la convocatoria de concursos a anunciar y comprender todas las plazas vacantes de la plantilla presupuestaria del Cuerpo a que se refiera, sino que en el ejercicio de sus prerrogativas de organización puede convocar el número de vacantes que resulten necesarias para la debida atención a las necesidades del servicio público».

Considerando: Que, consecuentemente, se desestima el recurso; sin hacerse especial condena de costas, pues faltan las circunstancias previstas en el artículo 131.1 de la Ley de 27 de diciembre de 1956.

Núm. 6. Sentencia de 21 de febrero de 1981. Contencioso-Adiminstrativo. Sala IV. Ponente, A. Martín del Burgo y Merchán. ARTICULO 33 DE LA CONSTITUGION.

Derecho de propiedad

Mera cita del artículo 33 de la Constitución.

\section{Antecedentes}

Sentencias de 27 de octubre de 1979 (núm. 12 del Repertorio de 1979) y 21 de junio de 1980 (núm. 5 bis del Repertorio de 1980). 
Constderando: Que, en supuestos como el presente, no se debe perder de vista que por mucho que se enfatice sobre la mutación sufrida por el derecho de propiedad en materia urbanística, hasta convertirse en un derecho de los llamados «estatutarios», su declinación, respecto del sentido que ha tenido en sus momentos de mayor esplendor, en los que le estaba permitido, en su ejercicio, hasta el ius abutendi, no puede llegar al extremo de reducirlo a un derecho inerme, totalmente sometido a cuantas prohibiciones y limitaciones tengan a bien adoptar las distintas autoridades administrativas, por rectas que sean sus intenciones; y no puede llegar a estos extremos porque la propiedad del particular sigue siendo algo más que una simple función pública o social, puesto que conserva su núcleo primario de derecho subjetivo, uno de los principales de los que integran la constelación de derechos de la personalidad, amparado en la cobertura legal que le proporciona el Código civil (artículos 348, 349, 350) y la propia Constitución española (artículo 33).

Considerando: Que, como consecuencia de lo dicho, al propietario no se le puede negar en principio el ejercicio del ius edificandi en cuanto constituye una de las facultades más genuinas de su derecho dominical, si bien el moderno derecho urbanístico ha impuesto sin desconocer tal derecho básico de la persona una racionalización del uso y aprovechamiento del suelo en función de las necesidades e intereses superiores de la colectividad, racionalización que parte de unas directrices e ideas básicas contenidas en la Legislación sobre Régimen del Suelo y Ordenación Urbana y que se completa con todo un sistema de planificación de desarrollo escalonado, sistema que tiene su remate, en la fase de ejecución, con los controles preventivos que proporciona la técnica de la licencia urbanística como instrumento dirigido a asegurar que el ejercicio de las facultades del propietario se produzcan, tal y como exige el artículo 76 de la vigente Ley del Suelo dentro de los límites y con el cumplimiento de los deberes establecidos en dicha ley y en los correspondientes planes de ordenación.

Considerando: Que la licencia, como acto de control preventivo, no es constitutivo, sino meramente declarativo de un derecho preexistente del administrado, ya atribuido por el ordenamiento urbanístico y por el derecho civil; la licencia no transfiere facultades, sino que remociona limites, por lo que en su otorgamiento o denegación se ha de actuar dentro de la más estricta legalidad (sentencias de 31 de octubre de 1958, 23 de octubre de 1964, 30 de abril de 1969, 12 de marzo de 1973, 24 de enero de 1978), pues la Administración no es libre para decidir si otorga o no la licencia, puesto que el contenido del acto ha de ser por entero reglado (sentencia de 3 de enero de 1975), lo que impide establecer restricciones discrecionales (sentencias de 24 de marzo de 1975 y 24 de enero de 1978) en cuanto el contenido del acto no depende del libre arbitrio o de la discrecionalidad de la Administración, pues ésta ha de actuar vinculada a los dictados de las normas y de los planes operantes en cada caso (sentencias de 8 de noviembre de 1972, 15 de enero de 1976 y 24 de enero de 1978).

Considerando: Que el principio de legalidad no sólo tiene que imperar en la conformación del contenido del acto, sino en la determinación del órgano administrativo que ha de intervenir (el Ayuntamiento del lugar, art. 179 de la Ley del Suelo), y hasta en el procedimiento que se ha de utilizar («se ajustará a lo prevenido en la legislación de Régimen Local», art. 178.3 de la Ley del Suelo); pues bien: en virtud de esto, el Reglamento de Servicios de las Corporaciones Locales de 17 de junio de 1955 es norma a tener en cuenta, y entre sus preceptos el contenido en su artículo 6, donde se establece que «el contenido de los actos de inter- 
vención será congruente con los motivos y fínes que lo justifiquen», y «si fueren varios los admisibles, se elegirá el menos restrictivo de la libertad individual».

Considerando: Que las anteriores consideraciones se hacen a efectos de estar debidamente prevenidos frente a la actitud del Ayuntamiento de Llissa de Vall, declarada conforme a derecho por el Tribunal de Barcelona, en virtud de la cual a la empresa accionante se le niega el derecho a la terminación de las obras proyectadas, a pesar de estar amparadas por licencia, por no haberlas terminado dentro del plazo de dos años concedida en el acto de su concesión, y a pesar de que en el mismo se preveía la posibilidad de conceder prórroga, so pretexto de haber aparecido unos datos que, a juicio de dicha corporación, impiden acceder a la solicitada prórroga.

Considerando: Que como se deduce de lo que acaba de exponerse, aunque el citado Municipio invoca como motivo para la denegación de la prórroga la aparición de unos datos nuevos, sin embargo, la causa que esgrime para llegar a una solución negativa para la empresa constructora no responde a la idea de revocación de la licencia por desaparición de las circunstancias que motivaron su otorgamiento o por sobrevenir otras, ni porque fuera otorgada por error, ni por adopción de nuevos criterios de apreciación (art. 16 del Reglamento de Servicios, antes citado), sino simplemente por caducidad de la misma al denegar el derecho a la prórroga, aunque para ello invoque determinadas razones.

Considerando: Que en principio no se puede hacer objeción a la operatividad del instituto de la caducidad en esta materia de licencias de urbanismo a pesar de que tan repetido Reglamento de Servicios permite que las licencias referentes a actividades personales puedan limitarse a plazo determinado (art. 15.2), mientras que guarda silencio sobre este extremo en las referentes a obras o instalaciones (art. 15.1), puesto que la jurisprudencia en términos generales viene permitiendo el sometimiento de las licencias a condición o carga modal (sentencias de 28 de. junio de 1955, 26 de diciembre de 1959, 23 de mayo de 1961 y 22 de diciembre de 1978), si bien algunas se refieren a condiciones en el sentido no propiamente tal, sino en el de condictio iuris (sentencias de 3 de diciembre de 1962, 15 de marzo de 1974 y 19 de enero de 1976), sobre todo por existir jurisprudencia permisiva de la aplicación de la caducidad en este tipo de licencias «en aras de la seguridad jurídica y en evitación de peticiones carentes de seriedad y con fines especulativos» (sentencias de 16 de junio de 1977 y 21 de enero de 1980), caducidad que viene prevista y regulada en muchas ordenanzas municipales, entre ellas, en las del Ayuntamiento de Madrid.

Considerando: Que partiendo de la base de la permisión de la caducidad en estas licencias, hay que tener presente que sus efectos no se producen automáticamente por el simple transcurso del tiempo por requerir un acto formal declarativo, adoptado tras de los trámites precisos, y con el derecho del afectado a su impugnación (sentencias de 13 de diciembre de 1952, 26 de junio de 1959, 25 de febrero de 1964, 26 de septiembre de 1975 y 16 de diciembre de 1977), aunque no falte alguna que otra sentencia contradictoria (sentencias de 13 de noviembre de 1975 y 25 de octubre de 1977); por otra parte, como en este caso la caducidad tiene por base el acto de concesión de la licencia (ignoramos si existen ordenanzas en el mencionado Municipio y, de existir, si en ellas se prevé este tema), no se puede manejar el problema de la caducidad sin al mismo tiempo tener en cuenta el de la posible prótroga de la licencia, puesto que tanto la fijación de un plazo para la realización de las obras como su posible ampliación vienen regulados en un mismo 
apartado del título de concesión de la licencia, obrante en el expediente administrativo.

Considerando: Que no se pueden disociar ambos aspectos porque los dos integran la voluntad única del Ayuntamiento en este caso, por lo que desconocer cualquiera de ellos representa el ir contra los propios actos, en contra del principio general prohibitivo de tal actitud (sentencia de 17 de diciembre de 1954); por ello no se debe declarar caducada una licencia si al titular de la misma se le ha reconocido un derecho a prórroga, y más si para negar la prórroga se invocan circunstancias que, como ocurre en el presente supuesto, ya existían en el momento inicial del otorgamiento de aquélla, por lo que, de tener el efecto obstativo que ahora se les atribuye, eso mismo debió servir para no conceder la autorización desde el primer momento.

Considerando: Que aún más insostenible resulta el acuerdo municipal de denegación de la prórrorga si se examinan los motivos invocados al efecto, puesto que, aparte de otros, traídos a colación de forma un tanto forzada, al resolver la reposición (varios preceptos de la Ley del Suelo, que no hacen al caso y cita del Reglamento de Actividades Molestas, Insalubres, Nocivas y Peligrosas a aplicar en la licencia de apertura, pero no aquí), el principal (el descubrimiento de unos caminos que con las obras pueden desaparecer) constituye un argumento totalmente especioso, puesto que por el trazado de esos caminos, según se aprecia en el plano incorporado a las actuaciones de la Audiencia, pertenecientes a la época en que estos terrenos eran de naturaleza rústica, llenos de curvas y recovecos, hay que felicitarse de su desaparición al carecer de sentido con el trazado de las nuevas vías de comunicación y acceso proyectadas, completamente regulares y rectilíneas y de mucha mayor anchura; mantener estos caminos no representaría otra cosa que mantener un puro estorbo, sin utilidad para nadie; sería gravar a un predio sirviente de forma inútil y estéril, desoyendo incluso las recomendaciones del Código civil para supuestos análogos (art. 545).

Considerando: Que como existen tantas razones para anular los acuerdos denegatorios de la prórroga de la licencia de que se trata, según han quedado expuestas, no es necesario adentrarse en otra más, que podría reforzarlas, como es la constituida por el abuso de poder que haya podido existir al pronunciarse el Ayuntamiento en este sentido y a la influencia que en ello haya podido tener la negativa de la empresa accionante a acceder a las pretensiones del alcalde sobre determinada obra a realizar por aquélla en una propiedad de este último. Se impone, pues, anular los actos administrativos en este proceso residenciados $y$, por consiguiente, revocar la sentencia apelada por pronunciarse en sentido contrario a esta conclusión.

Considerando: Que no es de apreciar temeridad ni mala fe en la conducta procesal de los contendientes a los efectos prevenidos en los artículos 81 y 131 de la Ley Jurisdiccional sobre imposición de costas.

Núm. 7. Sentencia de 27 de febrero de 1981. Contencioso-Administrativo. Sala V. Ponente, F. de Mateo Lage. ARTICULO 106.2 DE LA CONSTITUCION.

\section{Responsabilidad de la Administración}

Mera cita del artículo 106.2 de la Constitución, que consagra el principio de responsabilidad de la Administración consecuencia del funcionamiento de los servicios públicos. 


\section{Antecedentes}

Sentencia de 5 de noviembre de 1979 (núm. 14 del Repertorio de 1979).

Considerando: Que el apelante, titular de la finca núm. 198, polígono 108, en el Ayuntamiento de Siero, expropiada por el entonces Ministerio del Ejército para obras del plan de acuartelamiento de Asturias, impugna la sentencia dictada por la Sala de esta Jurisdicción de la Audiencia Territorial de Oviedo, en la que se fija el justiprecio de la finca por disconformidad con los pronunciamientos que en ella se hacen sobre dicho justiprecio, concretamente sobre el precio por metro cuadrado de que se deriva aquél, y la indemnización de daños y perjuicios como consecuencia de la devaluación monetaria, que, según el recurrente, hace que dicho justiprecio en el momento de percibirlo resulte muy inferior al que correspondería en ese momento.

Considerando: Que con respecto al avalúo de la parcela, cuya determinación por el Jurado Provincial de Expropiación Forzosa de Oviedo ha sido aceptada por el tribunal sentenciador en primera instancia, ha de reiterarse la doctrina establecida por esta Sala en repetidas ocasiones sobre la presunción de acierto de que gozan los acuerdos de los jurados, siempre que no se acredite que hayan incurrido en error evidente de apreciación o infringido preceptos legales, doctrina seguida en la sentencia recurrida al no advertir error o infracción normativa alguna en el justiprecio fijado por dicho jurado, y avalada por el reconocimiento judicial practicado por la Sala que la ha dictado y por su experiencia sobre la zona al haber conocido de casos análogos al aquí examinado; conforme, por otra parte, al criterio establecido en las sentencia de esta Sala, entre otras, de 7 de octubre de 1980 y 28 de enero de 1981, que versan en recursos de caractrísticas similares sobre fincas expropiadas para idéntico fin y situadas en el mismo término municipal, sin que frente a ello puedan acogerse los argumentos invocados por la parte apelante, pues ésta, tal como se expresó en las sentencias citadas al partir de una supuesta parcialidad y falta de conocimientos del funcionario técnico vocal del jurado, que se hacen derivar de su condición de funcionatio militar designado por el Ministerio del Ejército, incurre en una petición de principio, ya que tanto la condición como la forma de la designación de aquél son consecuencia de lo dispuesto en el artículo 100.2 de la Ley de Expropiación Forzosa, en relación con su artículo 32.1.b, cuando, como ocurre aquí, la expropiación responde a necesidades militares, por lo que las tachas que le opone el recurrente han de ser probadas, lo que no se ha hecho, y en cuanto a ciertas expectativas urbanísticas que se atribuyen en el recurso a la parcela expropiada para justificar el precio unitario defendido, fundadas en los informes periciales obrantes en las presentes actuaciones, tanto en el expediente administrativo como en el proceso, emitidos por ingenieros agrónomos, tampoco pueden tomarse en consideración, pues prescindiendo de otros motivos, la existencia y valoración de dichas expectativas no corresponde a la especialidad técnica de los peritos, habiéndose evaluado además expresamente el alcance de los dictámenes en la sentencia recurrida, desechándolos por no ajustarse a la realidad, entre cuyos informes ha de mencionarse el emitido en la fase procesal de prueba por la relevancia que le ha concedido esta Sala en otras ocasiones dadas las garantías que lo rodean, criterio que aquí no puede seguirse, ya que el precio unitario establecido en él no responde a la situación de la finca en el momento de la valoración, sino a unas previsiones de futuro expuestas sin datos concretos, conjugándose sus posibilidades de cultivo con las de su edificabilidad y transacciones de supuestos terrenos análogos, todo ello, como se ha indicado, sin referencias determinadas. 
ConsIDERANDo: Que en lo que respecta a los daños y perjuicios ocasionados como consecuencia de la devaluación monetaria, por lo que se solicita la actualización del justo precio, ha de reitetarse la doctrina de esta Sala expuesta, entre otras, en las sentencias de 30 de abril, 18 de junio y 3 de octubre de 1979, 18 de marzo, 6 y 7 de octubre de 1980 y 28 de enero último, estas dos últimas ya citadas, a tenor de la cual, y sintetizándola, «dicha devaluación en el procedimiento expropiatorio no tiene otros cauces legales de corrección que el abono de intereses establecido en la Ley de Expropiación Forzosa para la demora en la determinación del justo precio $y$, en su caso, de su pago, sin perjuicio de la facultad de acudir a la retasación prevista en el artículo 58 de aquélla», por lo que ha de desestimarse también este motivo de impugnación, aun cuando no pueda aceptarse el razonamiento que funda su desestimación en el tercer Considerando de la sentencia recurrida en cuanto a la exigencia de acreditar «el mal funcionamiento de los servicios públicos», entre otros requisitos, para que proceda la responsabilidad de la Administración, pues como se dice en las sentencias repetidamente citadas de 7 de octubre de $1980^{\circ}$ y $28^{\circ}$ de enero de este año, que contemplan supuestos iguales al presente, «esto contradice el tenor literal de los artículos 121.1 de la Ley de Expropiación Forzosa y 40.1 de la Ley de Régimen Jurídico de la Administración del Estado que acaba de mencionarse, ya que en ellos se deriva responsabilidad tanto del funcionamiento normal como del anormal de dichos servicios, consagrándose esta identidad de consecuencias para ambos supuestos en el artículo 106.2 de la Constitución vigente al referirse escuetamente al funcionamiento de los servicios públicos sin calificativo alguno, reflejando la sentencia impugnada una posición de la jurisprudencia ya superada, pues actualmente se sigue el principio de objetivación de la responsabilidad patrimonial de la Administración, como puede verse, entre otras, y por citar algunas de las más recientes, en las setencias de 6 y 12 de marzo, 27 de septiembre y 15 de noviembre de 1979 , sin que, por otra parte, esta corrección, hecha en cumplimiento del deber de fijar doctrina que recae sobre este tribunal, tenga relevancia en la desestimación de la pretensión enjuiciada».

ConsIDERANDo: Que como consecuencia de lo expuesto hasta aquí, ha de ser desestimado el recurso de apelación enjuiciado, confirmándose la setencia recurrida sin que haya motivo legal para la expresa imposición de costas.

Núm. 8. Sentencia de 21 de marzo de 1981. Civil. Ponente, J. Castro García. ARTICULO 28.1 DE LA CONSTITUCION.

\section{Libertad sindical: Derecho a crear o fundar sindicatos libremente}

El derecho a crear o fundar sindicatos libremente (arts. 7 y 28.1 de la Constitución) sólo puede ser ejercicio por trabajadores por cuenta ajena y, por consiguiente, por personas ligadas al empresario por contrato de trabajo. Aunque tal vínculo sea potencial por hallarse el interesado en situación de desempleo, no es lícita la creación de un sindicato integrado exclusivamente por desempleados.

\section{Antecedentes}

Sentencias de 11 de abril (núm. 3 del Repertorio de 1979), 6 y 15 de diciembre de 1979 (núms. 16 y 18 del Repertorio de 1979).

Considerando: Que según ha declarado esta Sala en referidas resoluciones que resuelven supuestos de práctica identidad con el presente (sentencias de 11 de 
abril y 6 y 15 de diciembre de 1979 , entre otras), la institución del Sindicato, grupo en el que se manifiesta la pluralidad asociativa creando un ente de interés público (artículo 35.1 del Código civil) con notas de permanencia y autonomía, tiene como una de sus condiciones definidoras, según general parecer de la doctrina científica, el carácter esencialmente representativo, ya que la profesión es la constante explicativa de su origen y desenvolvimiento en cuanto que la representación y defensa de los intereses profesionales constituye su primordial objetivo, amén de otros fundamentales, como son el logro por vía colectiva de la determinación de las condiciones de trabajo y la asistencia a los afiliados cuando se produzcan situaciones que la requieran, como acontece en las de desempleo para el trabajador y en las de crisis económica si se trata de los empresarios; y dado que el principio de profesionalidad informa todo el campo de esta manifestación asociativa hasta el punto de que se ha dicho que los Sindicatos encuentran su razón de ser y su fin en la solidaridad profesional, obligado es concluir con los autores que el ejercicio del derecho de sindicación, creando la persona jurídica que es substrato de aquéllos, exige como presupuesto indeclinable el efectivo ejercicio de una actividad, pues los móviles asistenciales (protección a parados, jubilados, etc.) siempre constituirán objetivos de menor rango que el más característico de la representación y defensa de los intereses de una determinada profesión, designio relevante y esencial que; en común opinión, entraña la justificación sociológica y jurídica del Sindicato mismo y a cuya luz han de ser interpretados los preceptos constitucionales que proclaman el derecho a la asociación profesional a sindicación.

Considerando: Que la característica expresada se traducirá, cuando de trabajadores se trate, en la exigencia de que el Sindicato habrá de asociar en rigor a los que lo sean por cuenta ajena y, por consiguiente, a personas ligadas al empresario por contrato de trabajo, aunque tal vínculo sea potencial por hallarse el interesado en situación de desempleo, requisito que late en las normas del Derecho positivo que admiten la constitución de Sindicatos, pues la general dicción del artículo 28.1 del vigente texto constitucional, como su equivalente del artículo 39 de la Constitución de 9 de diciembre de 1931, o la más vaga del artículo 13.4 de la de 30 de junio de 1876, ba de ser entendida acomodándola a la concreta normativa que regula el ejercicio de tal derecho, aunque libre, necesariamente ajustado a las exigencias legales que disciplinan su efectividad y que de manera inequivoca imponen el elemento profesional para la creación del Sindicato, según se desprende de las siguientes disposiciones con independencia de la filosofía política que las inspira: primera, la Ley de Asociaciones Profesionales de 8 de abril de 1932, primera normación orgánica sobre la materia, que desarrolló el citado precepto constitucional y la declaración de principios contenida en el artículo $4 .^{\circ}$ del Decreto de 14 de abril de 1931 alusivo a «la personalidad sindical y corporativa, base del nuevo derecho social», dispuso en su artículo $4 .^{\circ}$ que «solamente podrán ingresar en las asociaciones profesionales obreras los individuos mayores de dieciséis años que pertenezcan a los oficios o profesiones cuyos intereses obreros trate de defender la asociacionn, si bien el mismo precepto autorizaba a formar parte del Sindicato a «los obreros de uno y otro sexo que hayan pertenecido durante un año al menos a los oficios y profesiones correspondientes si no han adquirido la condición de patronos»; segunda, la Declatación 13 del Fuero del Trabajo de 9 de marzo de 1938 y la Ley Sindical de 17 de febrero de 1971, normas fundamentales citadas en el preámbulo de la Ley 19/1977, de 1 de abril, sobre regulación del derecho de asociación sindical, destacan el presupuesto de profesionalidad como básico del derecho de sindicación, pues si aquélla enunció que la Organización Sindical la constituyen los españoles «en cuanto participan en el trabajo y la producción», la segunda 
reproduce y desenvuelve el msimo postulado y asigna a los Sindicatos «constituidos por ramas de actividad la representación, defensa y promoción de los intereses profesionales) (arts. 1, 2, 4, 5 y 12), esto es, los «intereses peculiares determinados por la actividad económica o especialidad profesional de quienes constituyan» la asociación sindical (art. 13), cuyo relevante cometido en la fijación de las bases para la ordenación del trabajo y la negociación de los convenios colectivos señala el artículo 27; tercera, la Ley de 1 de abril de 1977, aún sin manifestación explícita sobre el particular, presupone que la defensa de los intereses profesionales respectivos de «los trabajadores y los empresarios» opera como razón primordial de la protección dispensada a la libertad de asociación sindical y califica la «rama de actividad» como ámbito de actuación económico o profesional (preámbulo y art. $1 .^{\circ}$ ), con lo que claramente da por sentado que los intereses para cuya defensa los trabajadores pueden fundar sindicatos son los que dimanan de las relaciones de trabajo, como así se infiere también del artículo 4.b del Estatuto de los Trabajadores de 10 de marzo de 1980 al mencionar la «libre sindicación» como uno de los «derechos laborales de los trabajadores»; cuarta, los Convenios números 87 y 98 de la Organización Internacionar del Trabajo, mencionados por esa regulación como marco a tener en cuenta, responden a la misma idea matriz de que el derecho de sindicación y la libertad sindical, por lo que a los trabajadores concierne, se predica de los que se hallan en actividad, según lo evidencian los artículos $2 .^{\circ}, 3^{\circ}$, $4 .^{\circ}, 5 .^{\circ}, 7 .^{\circ}$ y 10 del primero y los artículos $1 .^{\circ}$ ( «libertad sindical en relación con su empleo») y $4 .^{\circ}$ ( (reglamentar por medio de contratos colectivos las condiciones de empleo») del segundo de los Convenios citados; quinta, los trabajadores desempleados y los jubilados, que por lo dicho no están facultados para crear un Sindicato específico exclusivamente formado por quienes se encuentran en tales situaciones, no por ello dejan de estar protegidos por el derecho de asociación sindical, pues el artículo 6.b de la Ley 2/1971, de 17 de febrero, citada, autoriza a quienes se encuentren en paro para integrarse en el Sindicato [constituido, en primer término, por quienes son sujetos titulares de una relación jurídica laboral, según declara el párrafo a) del mismo precepto] mediante «su inscripción en el correspondiente registro sindical de colocación», y a su vez el Decreto 117/1973, de 1 de febrero, por lo que se regula la Sindicación y sus efectos, dispone que «los trabajadores técnicos que se hallen en situación legal de desempleo conservarán la plenitud de derechos y deberes en el Sindicato que corresponda» (art. 14), protección que asimismo es dispensada a los jubilados cumpliendo mínimas formalidades (art. 16, que da desarrollo al art. 11 de la Ley Sindical de 17 de febrero de 1971); sexta, la Ley de Seguridad Social, al tratar del desempleo y de la jubilación, conceptúa tales situaciones como pérdida de ocupación por parte de quienes «puedan y quieran trabajar» y «cesación en el trabajo por cuenta ajena por causa de edad», respectivamente (arts. 172 y 149), con el derecho consiguiente a las prestaciones legales, y puesto que la calificación jurídica de «trabajador» se adquiere con la de sujeto de un contrato de trabajo y no se produce a manera de efecto de un status permanente, habrá que entender que las referencias normativas al concepto de «trabajador», sin más circunstancias definidoras, atañe a quienes están ligados por una relación de trabajo, $y$, en consecuencia, el texto del ordenamiento positivo que gobierna el ejercicio del derecho de asociación sindical no consiente, por muy deseable que sea "la expansión de las asociaciones profesionales de base voluntaria», que los desempleados, pensionistas y jubilados, en cuanto tales, constituyan un Sindicato para afiliar exclusivamente a quienes carezcan de trabajo por encontrarse en paro forzoso o por haber alcanzado la edad de jubilación. 
Considerando: Que pasado ya al tema objeto del debate, el problema tratado en la instancia y traído ante este tribunal por recurso del Ministerio Público atañe a la posibilidad de dar curso legal a la Asociación denominada Trabajadores Parados de Cádiz, pretendida «al amparo de la Ley de 1 de abril de 1977 y disposiciones de desarrollo», según reza el artículo 1.० de sus Estatutos, cuyos miembros habrán de ser exclusivamente quienes reúnan las condiciones establecidas $\mathrm{y}$, por tanto, se circunscribe a «los trabajadores de la construcción en situación de paro o desempleo», así como los que se hallen integrados en empresas de la misma rama «que legalmente hayan solicitado reestructuración de plantillas para la suspensión o resolución de los contratos de trabajo», es decir, «los trabajadores de la construcción en paro o del puesto en situación de crisis» (arts. 2 y 4); solicitud a la que se opuso el Ministerio Fiscal por entender que tal Asociación no se ajusta a derecho, habiendo sido desestimada la demanda en ambas instancias.

Constderando: Que el primer motivo del recurso ha sido formulado al amparo del número $10^{\circ}$ del artículo 1.692 de la Ley de Enjuiciamiento civil y denuncia infracción por interpretación errónea del artículo 1.1 y 2 de la reptida Ley 19/ 1977, de 1 de abril, reguladora del derecho de asociación sindical, por entender que la Sala a quo ha incurrido en una interpretación contra legem de dicho precepto al tener por cortecta la constitución de un Sindicato integrado únicamente por personas que se hallan en situación de inactividad, motivo que debe prosperar, pues ciertamente a tenor de lo razonado no es dable erigir una Asociación Sindical conforme a dicha ley, integrada exclusivamente por quienes se hallan en situación de paro o crisis de trabajo, con lo que es patente la vulneración de los preceptos invocados, lo que conduce también a la estimación del motivo tercero, que por la propia vía reprocha al tribunal de instancia violación por inaplicación del artículo 1. ${ }^{\circ}$ de la Ley Reguladora del Derecho de Asociación de 24 de diciembre de 1974, ya que, en efecto, los componentes de la entidad combatida, por más "que carezcan del derecho a sindicarse en su específica condición de trabajadores desempleados, no están desprovistos de protección legal, que pueden alcanzar sin menoscabo alguno permaneciendo en el Sindicato que contaba con su afiliación cuando se hallaban en activo o acudiendo al cauce que les proporciona la libertad de asociación proclamadà en los artículos 1 y 2 de la Ley 191/1974, de 24 de diciembre.

CoNSIDERANDo: Que la estimación de ambos motivos hace innecesario el examen del segundo, basado en violación por inaplicación del artículo 11 de la Ley Sindical 2/1971, de 17 de febrero, en relación con el artículo 12 del Decreto 3.095/ 1972, de 9 de diciembre, y el artículo 16 del Decreto $117 / 1973$, de 1 de febrero, preceptos todos ellos atañentes a la situación de los jubilados y objeto de cita en los razonamientos precedentes.

Considerando: Que en virtud de todo lo expuesto, e incuestionable la competencia de la jurisdicción ordinaria y, a la postre, de este tribunal para conocer por razón de la materia según lo establecido en los artículos 11 a 15 de la Ley $62 /$ 1978, de 26 de diciembre, sobre Protección Jurisdiccional de los Derechos Fundamentales de la Persona, que deroga el Real Decreto 1.048/1977, de 13 de mayo, ha lugar al recurso entablado por el Ministerio Fiscal, procediendo, por consiguiente la casación de la sentencia impugnada y dictando por separado la correspondiente a tenor de lo ordenado en el artículo 1.745 de la Ley Procesal. 
Comentario

Véanse comentarios de las sentencias citadas en antecedentes.

Núm. 9. Auto de 27 de marzo de 1981. Criminal. Ponente, B. Gil Sáez. ARTICULO 117.5 DE LA CONSTITUCION.

Principio de unidad jurisdiccional

El principio de unidad jurisdiccional conlleva la expansión de la jurisdicción ordinaria y el constreñimiento de las jurisdicciones especiales y excepcionales a los específicos supuestos legales en los que les venga atribuida expresamente la competencia.

\section{Antecedentes}

Autos de 2 de mayo (núm. 3 del Repertorio de 1980), 26 de septiembre (núm. 16 del Repertorio de 1980), 14 de octubre (núm. 24 del Repertorio de 1980), 31 de octubre (núm. 29 del Repertorio de 1980) y sentencia de 22 de diciembre de 1980 (núm. 34 del Repertorio de 1980).

ConSIDERANDO: Que de los sucintos elementos de juicio aportados a esta Sala como antecedentes para dirimir la cuestión de competencia positiva por inhibitoria, suscitados entre la Audiencia Provincial de Madrid (sección 2.a) y la Capitanía General de la I Región de esta misma capital, se desprende sustancialmente a efectos competenciales: $1 .^{\circ}$ que por la Jurisdicción Militar Judicial de referencia se inició y tramitó la causa $16 / 78$ por el Juzgado Militar Permanente número 5 a virtud de haberse insertado en la publicación o periódico mensual denominado Juventud Obrera, número 131, de enero de 1978 un artículo, cuyo verdadero autor no ha sido identificado, del que es director Modesto González Lucas, en el que con el título «Me voy a la mili» se vierten expresiones presuntamente vejatorias contra el Ejército, al que califica de «fuerzas represivas», expresando además que en el ambiente castrense todo es «violencia, autoritarismo, miedo, aborregamiento, individualismo, impotencia, etc.», apreciándose además -a juicio del instructor- que de todo su contexto se desprende una evidente intención de desacreditar a las Fuerzas Armadas, lo que determinó el auto de procesamiento del director expresado con fecha 13 de febrero de 1978 , reputando que tales hechos pudieran ser constitutivos del delito de injurias al Ejército previsto y penado en el artículo $317 \mathrm{del}$ Código de Justicia Militar, del que sería responsable subsidiariamente aquél conforme el número 1 del artículo 197 del citado Código; $2 .^{\circ}$ que elevada conclusa la mencionada causa $16 / 78$ a la superioridad militar y encontrándose en trámite plenario, por el procesado director del periódico, Modesto González Lucas, se planteó formalmente ante la Audiencia Provincial cuestión de competencia por inbibitoria, sin baberlo previamente becho por declinatoria, mediante escrito firmado por letrado y procurador de fecha 20 de febrero de 1980, fundado en los artículos $10^{\circ}$ y $2 .^{\circ}$ de la Ley de 26 de diciembre de 1978 sobre ejercicio de los derechos fundamentales de la persona, entendiendo corresponder a la Jurisdicción Ordinaria la competencia y enjuiciamiento de los bechos perseguidos, así como en el artículo 117.5 de la Constitución prescribiendo el principio de unidad de jurisdicción; 3. que admitida a trámite la precitada cuestión y previo informe favorable del fiscal de la Audiencia, la sección $2 .^{a}$ de la misma, por auto de 15 de abril siguiente, tuvo por planteada dicha inhibitoria, y estimándose competente para su conoci- 
miento por los razonamientos aducidos por el promoviente, requirió de inhibición a la Autoridad Judicial Militar de la causa tramitada para su continuación y enjuiciamiento de los hechos contenidos en la misma; $4 .^{\circ}$ que recabados por dicha autoridad requerida los informes preceptivos, fueron emitidos por el fiscal jurídicomilitar y auditor general de la I Región Militar en el sentido de no proceder la inhibición interesada por los razonamientos que constan en sus respectivos dictámenes, acordándose por Decreto de 31 de julio del citado año del capitán general de esta Región Militar desestimar el requirimiento inhibitorio instado por la sección $2 .^{a}$ de la Audiencia y mantener su competencia para conocer de la causa cuestionada; $5 .^{\circ}$ que comunicada tal resolución a la sección $2 .^{a}$ requirente, ésta, por las consideraciones expuestas en su fundamento, acordó mantener a su vez su declarada competencia, y de acuerdo con la Ley de 17 de julio de 1948 sobre conflictos jurisdiccionales, comunicarlo a la autoridad judicial militar para remitir las diligencias en discordia a la resolución de este Alto Tribunal y Sala competente para dirimirla, y $6 .^{\circ}$ que recibidos los antecedentes respectivos de las diligencias ocasionadas por la cuestión competencial positiva de referencia, formalizado el rollo preceptivo de esta Sala y pasadas aquéllas a examen y dictamen del fiscal general del Estado, fue evacuado con fecha 20 de noviembre último, entendiendo por los razonamientos expuestos en aquél que la competencia debatida correspondía resolverla en favor de la Jurisdicción Especial Militar de la I Región para conocer de los hechos a que se contrae la causa $16 / 78$ de referencia instruida por la misma.

ConstDERANDo: Que al no haber sido aportada la causa instruida, los elementos de juicio se reducen fundamentalmente a los supuestos de hecho en que se basa el auto de procesamiento dictado por el Juzgado Militar permanente el 13 de febrero de 1978, y en especial de las frases transcritas en el mismo literalmente del artículo periodístico considerado vejatorio para el Ejército y Fuerzas Armadas, lo que al menos indiciariamente constituye un delito de «ofensa a los Ejércitos», que aunque cometido a través de la prensa y con publicidad, se encuentra - caso de comprobarse debidamente- especialmente tipificado en el artículo 317 del Código de Justicia Militar al derivarse del conjunto de su texto una clara intención maliciosa de desacreditar a las Fuerzas Armadas y, como secuela virtualmente deducible, la de suponer que lleva consigo, o tiene posibilidad de llegar a conseguirlo, una disminución de la indispensable unidad, disciplina y prestigio para el cumplimiento de sus primordiales deberes reconocidos en la Constitución y en sus Leyes Orgánicas propias, lo que es suficiente para deducir que los hechos enjuiciados hasta el momento de elevar las actuaciones a esta Sala de conflictos jurisdiccionales estuvieran incardinados en el artículo mencionado del Código penal común. referidos a corporaciones, instituciones o cuerpos de la Administración Civil del Estado, que tienen sujetos pasivos bien diferentes, cuya aplicación, por tanto, venía vedada a la Jurisdicción Ordinaria y atribuidas a la Castrense en razón a la repetida norma de finalidad militar, estaba encaminada con carácter prevalente a proteger el buen nombres, respeto y consideración de las Fuerzas Armadas y, como consecuencia mediata y obligada, a mantener su disciplina y buen orden interno, por lo que esta Sala, en supuestos iguales o análogos a la cuestión planteada, ha venido declarando con anterioridad que el referido artículo 317 comprendido en el capítulo IV, títu. lo IX, tratado $2 .^{\circ}$ del Código de Justicia Militar no había sido derogado por la Ley 62/78, de 26 de diciembre, de ahí que tratándose de.. delitos militares era obvio que su competencia se hallaba atribuida por el artículo 6.2 de aquel Código a la Jurisdicción Especial Castrense, máxime cuando el bien jurídico protegido por los artículos del capítulo mencionado afectaba tanto al honor militar como a la seguridad de los Ejércitos y del Estado, sin que los artículos $1 .^{\circ}$ y $20^{\circ}$ en sus distin- 
tos apartados ni la disposición transitoria 2 a $^{a}$ de la precitada Ley $62 / 78$ afectase a las ofensas inferidas por calumnia e injuria a la Autoridad Judicial Militar, Fuerzas Armadas o Ejército nacional, que quedaban específicamente incardinadas en la esfera de la Jurisdicción Militar.

Considerando: Que la precedente normativa citada, vigente con anterioridad al dictamen final del fiscal del Tribunal Supremo, ha sufrido una variación radical con la aprobación y publicación posterior de la Ley Orgánica $9 / 80$, de 6 de noviembre, reformadora del Código de Justicia Militar, que tiene plena vigencia a partir del 22 del citado mes, que si bien mantiene en esencia el texto primitivo del repetido artículo 317 , lo modifica y agrega un inciso final, estableciendo literalmente: «Incurrirán en la pena de prisión hasta seis años el que de palabra, por escrito o por cualquier medio de publicidad injurie a los Ejércitos o Instituciones, Armas, Clases o Cuerpos determinados de los mismos, siempre que el culpable fuese militar o el hecho se produzca ante un mando en presencia de sus tropas o en acuartelamiento, reciento o lugar militar", conjuntamente con la puesta en vigor del primitivo artículo 242 del Código penal (que se hallaba derogado por la Ley $3 / 67$, de 8 de abril), y cuyo literal texto dice: «Incurrirán en la pena de prisión menor los que injuriasen o amenazaren gravemente a los Ejércitos o a sus Instituciones, Armas, Clases o Cuerpos determinados. Cuando las injurias o amenazas no fueren graves se impondrá al culpable la pena de arresto mayor o multa de 50.000 a 100.000 pesetas», de cuyos textos legales aparece evidente que el supuesto delito genérico de ofensa a los Ejércitos, al que se contrae la causả número 16/78 contra el paisano Modesto González Lucas, ha dejado de ser de la competencia de la Jurisdicción Militar para entrar en la órbita de la Ordinaria tanto por razón del delito, al no estar el hasta ahora imputado comprendido en los ocho apartados o números del nuevo y modificado artículo $6 .^{\circ}$ del Código de Justicia Militar, como por razón del lugar, por no figurar cometido en los espacios de tierra, mar o aire a que se contraen los cinco números del artículo $90^{\circ}$ modificado del mismo Código, ni tampoco por razón de la persona responsable, al carecer el procesado de la condición o asimilación de índole militar precisada en los cuatro números que se especifican en el artículo 13 asimismo modificado del indicado Código, cabiendo agregar en apoyo de lo expuesto la modificación igualmente dispuesta en los artículos 16 y 21 del repetido Cuerpo legal militar reformado para atribuir la competencia y conocimiento de la causa seguida y cuestionada a la jurisdicción común ampliando el ámbito del artículo 10 de la Ley de Enjuiciamiento criminal en favor de la unidad de jurisdicción, que, como base normativa en materia de competencias jurisdiccionales, goza de carácter preferencial sobre los restantes de índole especial, dimanantes o segregadas de aquélla.

Por lo expuesto, esta Sala especial de conflictos jurisdiccionales AcuERDA: Que la cuestión de competencia positiva por inhibitoria planteada por la sección 2.a de la Audiencia Provincial de Madrid a la autoridad judicial de la I Región Militar sobre la causa número 16/78 seguida por el Juzgado Militar Permanente número 5 de la misma por supuesto delito de ofensa a los Ejércitos contra el procesado Modesto González Lucas sea resuelta a favor de la sección 2. a requirente, a la que se remitirán las actuaciones para su prosecución y terminación en derecho iniciadas por la Autoridad Judicial Militar requerida con notificación de lo resuelto a las citadas partes a los correspondientes efectos.

\section{Comentario}

Véanse sentencia y autos citados en el apartado de antecedentes. 
Núm. 10. Auto de 1 de abril de 1981. Criminal. Ponente, F. Gotta y Márquez de Prado. ARTICULO 24 DE LA CONSTItUCion.

Precepto penal sustantivo: el artículo 24 de la Constitución no lo es

El artículo 24 de la Constitución no es, a juicio de la sentencia, un precepto penal sustantivo $\mathrm{y}$, por consiguiente, su infracción no faculta la interposición de recurso de casación.

\section{Antecedentes}

Sobre el artículo 24 , que no sobre la doctrina que se mantiene en esta sentencia, pueden verse las sentencias de 5 de noviembre de 1979 (núm. 13 del Repertorio de 1979), 30 de mayo (núm. 5 del Repertorio de 1980), 3 de julio (núm. 9 del Repertorio de 1980) y 24 y 26 de septiembre de 1980 (núms. 17 y 16 del Repertorio de 1980).

Considerando: Que a tenor de lo prevenido en el artículo 874 de la Ley de Enjuiciamiento Criminal y a constante jurisprudencia que lo interpreta, es requisito esencial para la admisión de un recurso de casación por infracción de ley fundado en el número $1 .^{\circ}$ del artículo 849 de la mencionada disposición procesal la cita que ha de hacerse del precepto penal de carácter sustantivo que se suponga quebrantado en su aplicación o. inaplicación por el tribunal de instancia, y siendo así que el recurrente no cumple en el presente caso con tan elemental exigencia, por cuanto los preceptos que alega como violados, que son el artículo 1.214 del Código civil y el 24 de la Constitución española, carecen de tal carácter por no ser preceptos penales sustantivos; es indudable que por tal omisión no es admisible el interpuesto como motivo segundo de casación por prohibirlo expresamente el número $4 .^{\circ}$ del artículo 884 de la citada Ley de Procedimientos penales.

No ha lugar a la admisión del motivo segundo del recurso de casación por quebrantamiento de forma e infracción de ley interpuesto por la representación del procesado O. F. R. contra sentencia pronunciada por la Audiencia de Orense en fecha 15 de noviembre de 1980 en causa seguida contra dicho procesado por delito de estupro, y en cuanto a los motivos primero y tercero de dicho recurso, se declaran admitidos y conclusos, señalándose día para el fallo del mismo cuando por turno le corresponda. Comuníquese a su tiempo esta resolución al tribunal sentenciador a los efectos legales oportunos, y en cuanto a costas en su día, se acordará. Y publíquese en la Colección Legislativa.

\section{Comentario}

La doctrina del auto de 1 de abril de 1981 no deja de ser sorprendente por la interpretación que se hace del apartado $10^{\circ}$ del artículo 849 de la Ley de Enjuiciamiento criminal, así como por la naturaleza que se atribuye al artículo 24 de la Constitución. En efecto, se discute la naturaleza del artículo 24 como precepto penal sustantivo siguiendo en cierto modo la tendencia de la sentencia de 24 de septiembre de 1980 (núm. 17 de 1980) y contra el criterio de sentencias como la de 5 de noviembre de 1979 (núm. 13 de 1979), que supone la aplicación directa del artículo 24 de la Constitución. Pero aunque se discutiera la naturaleza penal del artículo 24 , éste sería operativo en cuanto precepto de aplicación directa al supuesto que ocupa la sentencia, por cuanto el citado artículo 849.1 de la Ley de Enjuiciamiento criminal establece que debe entenderse infringida la ley al efecto de interponer recurso de casación cuando se infrinja una norma jurídica de 
carácter sustantivo que deba ser observada en la aplicación de la ley penal, y no cabe duda de que la aplicación de la ley penal debe tener en cuenta el supuesto del artículo 24 de la Constitución.

La posición que ocupa en la Constitución el artículo 24 no debe permitir, aunque esto ha tenido lugar en alguna de las sentencias que citamos, otra interpretación que la de que se trata de un precepto de directa aplicación.

\section{Núm. 11. Sentencia de 3 de abril de 1981. Criminal. Ponente, B. F. Castro Pérez. ARTICULO 12 DE LA CONSTITUCION.}

\section{Mayoría de edad}

Según la sentencia, la mayoría de edad civil no tiene por qué coincidir con otras mayorías de edad u otras edades, a las que se dota a algunos efectos de especial protección.

Constderando: Que el único motivo del recurso interpuesto por T. S. E. no puede ser acogido al constar como probado en la narración fáctica de la resolución impugnada que la recurrente era dueña de la cafetería citada, en la que prestaban sus servicios como camareras las otras dos procesadas, y en la cual desde hacía ya tiempo éstas venían ocupándose con los clientes, percibiendo por ello cantidades de dinero que repartían con la primera, actividad que configura el delito de favorecimiento de la prostitución descrito en el número $1 .^{\circ}$ del artículo 452 bis, d) del Código penal, por el que viene penada la recurrente, puesto que favorecer la prostitución es facilitar su ejercicio, facilitación que consistió en este caso en poner a disposición de su citadas empleadas el local para que éstas, en su función de camareras, pudieran exhibirse y entregar su cuerpo a los lúbricos apetitos de los clientes que concurrían a su establecimiento y las solicitaban para cohabitar sexualmente con ellas, que es lo que se designa en la sentencia de instancia con el vocablo «ocuparse», que, como es notorio, significa eufemísticamente la conjunción carnal voluntaria, con lo que ejercía una función de intermediación sexual Jucrativa de proxenetismo o alcahuetería, que es lo que el legislador quiere castigar en el citado precepto y demás concordantes.

Considerando: Que para el mejor enjuiciamiento del segundo recurso es necesario tener en cuenta qüe una acción humana para ser calificada legalmente como sexualmente corruptora e incardinada en el tipo penal descrito en el artículo 452 bis, b), número $1 .{ }^{\circ}$, debe poseer la necesaria potencialidad para perturbar o alterar profundamente el desenvolvimiento o desarrollo de la sexualidad en el sujeto pasivo, incitándole a la práctica de actividades sexuales pervertidas, prematuras o desviadas, por lo que el coito normal realizado por muchos mayores de catorce años (edad considerada por las reglas canónicas de la Iglesia católica tomadas como exponente de la cultura occidental como apta para poder contraer matrimonio los varones) con mujeres mayores de edad ya prostituidas no puede estimarse que reúna tales características depravantes para ser considerado delictivo para lo que se requeriría además según tiene declarado reiteradamente esta Sala (sentencias de 21 de noviembre de 1972, 26 de mayo de 1975, 13 de diciembre de 1977, 18 de enero y 22 de diciembre de 1978) no un simple acto aislado, sino un proceso de cierta continuidad y permanencia, capaz abstractamente de crear en la mente del menor una alteración o modificación psíquica o reflejo condicionado que pudiera influir de manera desfavorable en el desenvolvimiento instintual futuro de la persona afectada, por lo que procede la estimación del único motivo de dicho recurso, al que figura adherido el Ministerio Fiscal. 
CONSIDERANDO: Que planteado en el segundo otrosí del escrito de formalización de este segundo recurso la cuestión de la inconstitucionalidad del artículo 452 bis, b) en su numero primero por contradicción con el artículo 12 de la Constitución que fija la mayoría de edad de los españoles en los dieciocbo años, solicitando en el mismo la iniciación de una cuestión de inconstitucionalidad al amparo de lo preceptuado en el artículo 35 de la Ley Orgánica del Tribunal Constitucional, tal petición no puede ser atendida no sólo porque dicha cuestión al no haber sido promovida en instancia debe ser considerada en la casación como cuestión nueva $\mathrm{y}$, por tanto, rechazable, sino también y sobre todo porque la aparente discrepancia denunciada entre el precepto constitucional y el penal no tiene realidad práctica, ya que nada impide que el legislador fije el límite de la protección penal por encima o más allá de la mayoría de edad, como ya venía sucediendo bajo el imperio de la legislación anterior, donde la mayoría de edad se alcanzaba a los veintiún años, mientras que la protección penal se extendía, como ahora, hasta los veintitrés años, no pudiendo olvidarse por otra parte que en el presente proceso la cuestión resulta totalmente irrelevante, pues los citados jóvenes presuntas víctimas de la pretendida corrupción lo serían en todo caso al ser menores de dieciocho años, fuese cualquiera de las dos edades la que se estableciera como límites de protección, intrascendencia que exime a esta Sala de la iniciación y tramitación del expediente de inconstitucionalidad solicitado.

CONSIDERANDO: Que en referencia a la otra cuestión planteada asimismo en dicho otrosí, consistente en denunciar que los redactores del texto articulado del Código penal de 1963 se excedieron en las atribuciones delegadas que le concedía la Ley de Bases de 1961, al no recoger en dicho texto el requisito de la habitualidad que no estaban autorizados para suprimir, como lo hicieron finalmente en el texto revisado, tal cuestión tampoco puede ser suscitada a través de un recurso de anticonstitucionalidad, ya que ni la citada ley de Bases dada para aquella única ocasión tiene en la actualidad fuerza de ley, como exige el artículo 161.1 de la Ley Constitucional, ni resulta tampoco procedente la aplicación del artículo 82 de la misma, porque tal precepto contiene una reglamentación de la delegación legislativa para el futuro, pero no con respecto al pasado, en el que el abuso de tal potestad delegada sólo podía ser objeto del control judicial, como tiene declarado esta Sala en sentencia de 2 de julio de 1980, aparte de que todo ello carecería de eficacia práctica, puesto que la sentencia de instancia da como probada la existencia de tal habitualidad al declarar con dicho carácter que tanto la dueña como las camareras recurrentes venían dedicándose a las inmorales actividades reseñadas anteriormente desde hacía tiempo, por lo que es necesatio estimar la habitualidad de tales conductas en el caso de autos, que serían delictivas, aunque en el texto reformado del Código hubiese seguido exigiéndose el citado requisito o elemento típico si no fuera porque al requerirse la continuidad de la conducta corruptora de los recurrentes, que aquí no aparece demostrarda, hay que absolver a la recurrente de dichos delitos, con lo que la cuestión propuesta queda sin relevancia efectiva, procediendo la estimación de su recurso.

Considerando: Que como tiene solicitado el Ministerio Fiscal en su adhesión al recurso, los efectos absolutorios del interpuesto por M. N. R. han de ser extendidos a su coprocesada C. O. L., no recurrente, por hallarse en la misma situación y serle apicable el motivo estimado, que da lugar a la casación y produce la libre absolución de ambas del delito del que se les acusa.

Fallamos: Que debemos declarar y declaramos haber lugar al recurso de casación por infracción de ley interpuesto por la representación de la procesada 
M. A. N. R., al que se adhirió el Ministerio Fiscal, cuyos efectos han de extenderse a su coprocesada C. O. L. por hallarse en la misma situación ambas, y en virtud casamos y anulamos la sentencia dictada por la Audiencia de Valencia de fecha 29 de febrero de 1980 en causa seguida a las mismas por el delito relativo a la prostitución, declarando de oficio las costas. Y No HA LUGAR al recurso interpuesto por la representación de la procesada T. S. E., a la que condenamos al pago de las costas y a la cantidad importe del depósito si llegare a mejor fortuna. Comuníquese esta sentencia y la que a continuación se dicta a la referida Audiencia a los efectos legales procedentes.

\section{SEGUNDA SENTENCIA}

Excelentísimos señores don Bernardo Francisco Castro Pérez, don Antonio Huerta Alvarez de Lara y don Fernando Cotta y Márquez de Prado.

En Madrid, a 3 de abril de 1981.

En la causa incoada en el Juzgado de Instrucción de Valencia número 5 y seguida en la Audiencia de la misma ciudad por el delito de relativo a la prostitución contra M. N. R., de veinticuatro años de edad, hija de Pedro y de María, natural de Segovia y vecina de Valencia, calle Dama de Elche, número 22, de estado soltera, de profesión estudiante, de mala conducta, con instrucción, sin antecedentes penales, insolvente $y$ en libertad provisional por esta causa, en la que ha estado privada de ella desde el día 15 al 18 de septiembre de 1978; T. S. E., de treinta y seis años, hija de José y de Teresa, natural de Granada, vecina de Valencia, calle José Aguilar, número $6,7^{\circ}$, soltera, industrial, de mala conducta, con instrucción, sin antecedentes penales, insolvente y en libertad provisional por esta causa, en la que ha estado privada de ella desde el día 15 al 18 de septiembre de 1978 , y contra C. O. L., de veinticuatro años, hija de Angel y de Carmen, natural de San Clemente (Cuenca), vecina de Valencia, Avenida del Puerto, número $209,1 .^{\circ}, 2 .^{a}$, casada, sus labores, de mala conducta, con instrucción, sin antecedentes penales, insolvente y en libertad provisional por esta causa, en la que ha estado privada de ella desde el día 15 al 18 de septiembre de 1978, en cuya causa se dictó sentencia por la referida Audiencia con fecha 29 de febrero de 1980 , la cual ha sido casada y anulada por la pronunciada por este Tribunal Supremo en el día de hoy. Siendo ponente el excelentísimo señor magistrado don Bernardo Francisco Castro Pérez.

Aceptando los resultados de la resolución recurrida y

Considerando: Que las procesadas en esta causa, M. A. N. R. y C. O. L, a pesar de haber tenido acceso carnal en la ocasión de autos con muchachos menores de dieciocho años, no pueden ser consideradas autoras de un delito de corrupción de menores del número primero del artículo 452 bis, $b$ ), del que vienen acusadas por el Ministerio Fiscal, ya que tal acción realizada una sola vez carece de la continuidad y persistencia exigidas jurisprudencialmente para que su conducta pueda ser estimada como corruptora, por lo que procede la libre absolución de ambas.

Considerando: Que respecto a la otra procesada, T. S. E., que como dueña del establecimiento que se cita venía permitiendo que las mujeres anteriormente citadas que alli trabajaban a sus órdenes como camareras yaciesen con los clientes del mismo dentro del local mediante el pago de determinadas cantidades, de las que ella percibía un tanto por ciento, facilitando con ello el ejercicio de la prostitución por las citadas camareras, hay que calificar su conducta como encuadrada en el tipo penal escrito en el número primero del artículo 452 bis, b), 
del Código penal, del que, por tanto, debe ser considerado autora, sin la concurrencia de circunstancias modificativas de la responsabilidad criminal.

Vistas las disposiciones citadas y demás pertinentes de general aplicación,

Fallamos: Que debemos condenar y condenamos a la procesada en esta causa, T. S. E., como responsable en concepto de autora de un delito de favorecimiento de la prostitución, sin la concurrencia de circunstancias modificativas de responsabilidad criminal, a las penas de tres años de prisión menor, multa de 30.000 pesetas e inhabilitación especial para desempeñar todo cargo o función tutelar sobre menores en su educación o guarda por tiempo de nueve años, accesorias de suspensión de todo cargo público, profesión u oficio y derecho de sufragio durante el tiempo de cumplimiento de la condena de privación de libertad, así como al pago de las costas procesales originadas por esta causa en su tercera parte y cierre del establecimiento de cafetería que se menciona como de su propiedad por tiempo de tres años, absolviendo a las otras dos procesadas, M. A. N. R. y C. O. L. del delito de corrupción de menores, del que venían acusadas con declaración de oficio de las dos terceras partes de costas que les correspondería pagar si hubieran sido condenadas. Y diríjase orden telegráfica a la Audiencia de Valencia a fin de que si la procesada C. O. L. estuviere en prisión se acuerde su inmediata libertad. Núm. 12. Sentencia de 8 de abril de 1981. Criminal. Ponente, J. H. Moyna
Ménguez. ARTICULOS 16.1 Y 3 DE LA CONSTTUCION.

\section{Confesión religiosa: ninguna tendrá carácter estatal}

No obstante, no tener ninguna confesión carácter estatal conforme al artículo 16 de la Constitución, siguen vigentes los preceptos del Código penal, que condenan los actos de profanación y ofensa a los sentimientos religiosos de la comunidad, que justifican la actuación del Ministerio Fiscal conforme a lo establecido en el artículo 105 de la Ley de Enjuiciamiento criminal.

Considerando: Que el primer motivo del recurso, amparado en el artículo 849, primero, de la Ley de Enjuiciamiento criminal, cita el artículo 209 del Código penal, y el artículo 16.3 de la Constitución española, arguyendo que, al no tener ninguna confesión carácter estatal, el procedimiento por delitos que atenten contra la religión católica ba de incoarse mediante «querella de quien tenga la representación legal de dicba confesión $e$ incluso de cualquier ciudadano como tal, sin que el Ministerio Fiscal se erija en representante de una religión cuyo vínculo con el Estado no existe»; y en el tercer motivo y último de los admitidos, por el cauce de la misma vía procesal se invoca la no aplicación del artículo $2 .^{\circ}$, número 1 , y artículo $4 .^{\circ}$, número 1 , de la Ley de 26 de diciembre de 1978 sobre Protección Jurisdiccional de los Derechos Fundamentales de la Persona, alegando que entre éstos se encuentra el de libertad religiosa con la exigencia legalmente impuesta de que se proceda en virtud de denuncia de la persona agraviada o, en su caso, de su representante legal.

Considerando: Que puede advertirse sin gran esfuerzo deductivo que los motivos en que centra el recurso tratan de llevar al campo de los delitos privados o de los llamados semipúblicos las infracciones previstas en el título II, capítulo II, sección $3 .^{a}$, del Código penal, propiciando una interpretación extensiva del artículo 104 de la Ley de Enjuiciamiento criminal y haciendo cuestión de la persegui- 
bilidad de estos delitos, que por su «novedad» procesal justificaría - sin más argumentos- la desestimación, y dicha pretensión se intenta apoyar alternativamente en la Constitución y en la Ley de Protección Jurisdiccional de los Derechos Fundamentales de la Persona, sin advertir que lo religioso no es un aspecto o un valor accesorio o circunstancial, sino esencial de la persona, y como tal garantizado por la Constitución española (art. 16.1), extendiéndose esta garantia o protección en el ámbito penal a la libertad (art. 205 del Código penal), a la libertad de culto (artículo 207), ambas libertades con la extensión reconocida en la Ley Orgánica de 5 de julio de 1980 (art. 2.0), y a los sentimientos religiosos, tipificando en los artículos 208 y 209 del texto penal los actos de profanación y ofensa, y estos actos no suponen un agravio o ultraje a una persona determinada, sino a los sentimientos religiosos de la comunidad en razón a que el becho religioso es un valor comunitario, colectivo o social de primera magnitud, y como tal asumible $y$ asumido por la imparcial magistratura del Ministerio Fiscal dentro del campo de actuación que acosa el artículo 105 de la Ley de Enjuiciamiento criminal, de suerte que a sus instancias pudo seguirse y se siguió el procedimiento penal por actos de público ultraje a los sentimientos religiosos de la comunidad católica, materializados en la soez burla de las personas religiosas y de sus dogmas y ritos que describe el Resultando de hechos probados, y es, por último, meridianamente desacertada la referencia hecha a la Ley de Protección Jurisdiccional de 1978 no sólo por el carácter adjetivo de los preceptos citados, sino porque los actos perseguidos no atentan en estricto sentido contra la libertad religiosa, sino contra los sentimientos religiosos, y aunque guarden ciertas afinidades con el delito de injuria conforme ha subrayado la doctrina jurisprudencial al examinar el elemento subjetivo, el hecho de que el bien jurídico protegido sean los sentimientos religiosos de la comunidad y no los de una persona determinada impediría la aplicación extensiva de lo dispuesto en el artículo $4 .^{\circ}$, primero, de la Ley citada para los delitos de injuria hechos por escrito y con publicidad; razones todas que conducen a la desestimación de los motivos de casación admitidos.

\section{Núm. 13. Auto de 23 de abril de 1981. Criminal. Ponente, M. Gómez de Liaño Cabaleda. ARTICULOS 24.2 Y 53.1 DE LA CONSTITUCION.}

Mera cita de los artículos 24.2 y 53.1 de la Constitución.

\section{Antecedentes}

Sentencias de 5 de noviembre de 1979 (núm. 13 del Repertorio de 1979), 30 de mayo (núm. 5 del Repertorio de 1980), 3 de julio (núm. 9 del Repertorio de 1980), 24 y 26 de septiembre de 1980 (núms. 17 y 16 del Repertorio de 1980) y 17 de febrero de 1981 (núm. 4 de este Repertorio) y 1 de abril de 1981 (núm. 10 de este Repertorio).

Considerando: Que el primer motivo del recurso se articula al amparo del número $20^{\circ}$ del artículo 849 de la Ley de Enjuiciamiento criminal -error de hecho en la apreciación de la prueba - al fundamentarse en que el mismo deriva de las diligencias de careo entre la ofendida y el procesado, así como entre aquélla y un testigo, y de las declaraciones de los mismos durante el proceso, y muy especialmente en el acto del juicio oral, no debe ser admitido de conformidad con el número $6 .^{\circ}$ del artículo 884 de la Ley Procesal citada, que determina como causa de inadmisión del recurso cuando los documentos en que se apoye el error no tengan la naturaleza de auténticos, y las diligencias de careo y declaraciones 
del procesado y de testigos no lo tienen en cuanto que su contenido no es indubitado, y este carácter es requisito intrínseco de la autenticidad documental según criterio reiterado de la jurisprudencia de esta Sala.

Considerandos Que el artículo 884 acabado de citar en el anterior considerando igualmente determina como causa de inadmisión de los motivos casacionales, en el número $3 .^{\circ}$, cuando en las argumentaciones de su fundamentación se falte al debido respeto que reclaman los hechos probados en todos los supuestos del recurso de casación, menos cuando se articule al ampato del número 2 del artículo 849 de la ley; el segundo y último motivo formulado también debe ser inadmitido, pues de su análisis se desprende de modo claro y evidente que el contenido de los razonamientos empleados para la demostración de la existencia del motivo descansa en las declaraciones prestadas por un testigo y el carácter dubitativo que encierran los hechos ante las mismas, y ello pone de relieve la irrespetuosidad fáctica en cuanto que los supuestos de hecho se tratan de desvirtuar por medios probatorios que fueron tenidos en cuenta por el tribunal de instancia, sin que esta inadmisión implique violación de los artículos 24.2 y 53.1 de la Constitución en cuanto que la normativa reguladora del derecho a las garantias procesales no se vulnera por la inadmisión de los cauces invocados para su pretendida defensa.

\section{Núm. 14. Sentencia de 29 de abril de 1981. Criminal. Ponente, M. Gómez de Liaño y Cobaleda. ARTICULO 24, DE LA CONSTITUCION.}

\section{Derecho a utilizar los medios de prueba pertinentes}

El derecho a utilizar los medios de prueba pertinentes conforme a lo establecido en el artículo 24.2 tiene, en relación al artículo 850 de la Ley de Enjuiciamiento criminal, que estar sujeto a una serie de requisitos determinantes de su pertinencia.

\section{Antecedentes}

Sentencias de 5 de noviembre de 1979 (núm. 13 del Repertorio de 1979), 30 de mayo (núm. 5 del Repertorio de 1980), 3 de julio (núm. 9 del Repettorio de 1980), 24 y 26 de septiembre de 1980 (núms. 17 y 16 del Repertorio de 1980) y 17 de febrero (núm. 4 de este Repertorio de 1981), 1 y 23 de abril de 1981 (núms. 10 y 13 de este Repertorio de 1981).

Considerando: Que como tiene reconocido esta Sala reiteradamente - sentencias 30 de octubre de 1980, 17 de enero y 13 de febrero de 1981, entre otras-, el motivo casacional del número primero del artículo 850 de la Ley de. Enjuiciamiento criminal - denegación de prueba pertinente propuesta en tiempo y forma- tiene su razón de ser en la protección y desarrollo del derecho que consagra la Constitución en su artículo 24 «a utilizar los medios de prueba pertinentes para su defensa», frase que implica el reconocimiento de un derecho procesal con la limitación de la pertinencia en el sentido de que puede ser denegado en aras de la efectividad del trámite procesal cuando sea impertinente, por lo que esta misma Sala en las resoluciones antes citadas tiene declarado que, para al viabilidad de la casación ante la negativa probatoria del tribunal de instancia, es necesario: $1 .^{\circ}$ Que el motivo probatorio sea propuesto en el momento procesal adecuado y con las formalidades legales; $20^{\circ}$ Que conste la denegación de la prueba propuesta, bien en la admisión o en la práctica; $3 .^{\circ}$ Que no sea impertinente, bien su consecuencia 
material en cuanto que es preciso que la prueba tenga relación con el objeto del proceso o en su conexión funcional, ya que es necesario que esté encaminada al conocimiento de los hechos; $4 .^{\circ}$ Que se dé a conocer el contenido del medio probatorio propuesto con la finalidad de apreciar su pertinencia o impertinencia, y con ello evitar la indefensión proscrita legalmente con rango constitucional; 5. $Q$ Que se haga constar la correspondiente protesta como justificante del patitum de la subsanación y la no aquiescencia al defecto procesal.

Considerando: Que del examen de la inadmisión de la prueba se deduce de modo evidente: que fue propuesta en el momento procesal oportuno y cumpliendo las formalidades legales en cuanto que se formuló al evacuar el escrito de calificación o de conclusiones provisionales, de conformidad con lo preceptuado en el artículo 656 de la Ley de Enjuiciamiento criminal; que el tribunal de instancia la denegó por auto, en el que a su vez se acordaba la admisión del resto de los medios probatorios propuestos y el señalamiento del juicio oral; que tenía conexión material con el proceso, en cuanto que se relacionaba con el objeto del mismo o enjuiciamiento de un supuesto delito de violación; que se hizo constar el contenido de la misma, ya que se especificaron los extremos sobre lo que recaía, y que asimismo se expresó la correspondiente protesta, como requisito formal que reclama la viabilidad del motivo formulado. Por todo ello se pone de relieve que, sin lugar a duda, concurren los condicionamientos que la impugnación casacional reclama, excepto el relativo a la conexión funcional o necesidad de ser practicado para llegar al claro conocimiento de los hechos, que no se puede apreciar, pues estando fundados los medios probatorios en una inspección ocular para que se hiciere constar «el itinerario que hay que seguir desde el Rincón de Soto hasta la finca de Ortigosa, paso de puentes, uso de caminos vecinales, distancia apreciada con cuentakilómetros, etc.», declaración en el lugar de los hechos de un testigo «para que depusiere cómo halló determinados objetos dentro de la finca» y para que al procesado y a la víctima se les tome declaración en el lugar en que tuvo lugar el acceso carnal, sobre los extremos «de cómo entraron en el mismo, cómo apilaron los papeles, etc.», y el punto a esclarecer se refiere a si hubo o no asentimiento por parte de la ofendida en el yacimiento; la negativa no produce indefensión alguna en cuanto que el contenido de la inspección ocular no aclara lo más mínimo el extremo deseado, y las declaraciones pedidas se admitieron como interrogatorio del procesado y prueba testifical. Por todo lo cual el único motivo del recurso debe ser desestimado.

\section{Comentario}

Véanse comentarios a las sentencias citadas en antecedentes. 